\section{CRYSTAL STRUCTURE AND MAGNETIC PROPERTIES OF}

\section{$\operatorname{Pr}_{1-\mathrm{x}} \mathrm{Tb}_{\mathbf{x}} \mathrm{Mn}_{2} \mathrm{Ge}_{2}$}

A. Elmali Y. Elerman E. Duman M. Acet

Ankara University, Faculty of Engineering Engineering Physics Ankara University, Faculty of Engineering Engineering Physics ANKARA 06100 BESEVL TURKEY

Temperature and field dependence of the magnetic behavior of magnetic moments of the rare earth and $\mathrm{Mn}$ sublattices of $\mathrm{RMn}_{2} \mathrm{Ge} 2$, where $\mathrm{R}$ is a rare earth element, leads to a variety of interesting magnetic properties. These compounds crytallise in the tetragonal $\mathrm{ThCr}_{2} \mathrm{Si}_{2}$ type crystal structure with space group $14 / \mathrm{mmm}$ which consist of layers along the c-axis with sequence RGe-Mn-Ge-R. When light rare-earth elements ( Pr, La, Ce or Nd) use in title compounds, the interlayer magnetic coupling in the $\mathrm{Mn}$ sublattice is ferromagnetic, whereas it is antiferromagnetic in the case of Gd, Tb or Dy. At low temperatures, the rare earth sublattice also orders and reconfigures the ordering in the Mn sublattice. In this study, crystal structure and magnetic properties of $\operatorname{Pr}_{1-\mathrm{x}} \mathrm{Tb}_{\mathrm{x}} \mathrm{Mn}_{2} \mathrm{Ge}_{2}$ compounds were investigated by X-ray diffraction and magnetic measurements. The results of earlier neutron diffraction and Mössbauer studies on samples with $\mathrm{x}=0$ and $\mathrm{x}=1$ are also used for interpreting the magnetization data and to give an account on the competing effects between various magnetic structures in the $\mathrm{Mn}$ and rare earth sublattices. In low field, we have observed that, temperature dependence of zero field cooled and field cooled magnetizations shows large difference at the Curie temperature of $\mathrm{Mn}$ sublattices $\left(\mathrm{T}_{\mathrm{C}}\right)$. This behavior is related to pinnnig of the ferromagnetic components of $\mathrm{Mn}$ sublattices and proved that there is an antiferromagnetic ordering of $\mathrm{Mn}$ sublattices with Neel temperature $\mathrm{T}_{\mathrm{N}}>$ $\mathrm{T}_{\mathrm{C}}$,which has been observed only by using neutron diffraction techniques.

\section{Keywords: LAYERED MAGNETIC STRUCTURE, RARE EARTH MAGNETISM, PINNING}

Acta Cryst. (2002). A58 (Supplement), C157

\section{CRYSTAL STRUCTURE AND SUPERCONDUCTING PROPERTIES} $\mathrm{OF} \mathrm{Sr}_{2} \mathrm{YCu}_{2}(\mathrm{Fe}, \mathrm{Co}) \mathrm{O}_{6+\delta}$

T. Mochiku $^{1}$ Y. Hata $^{2}$ Y. Mihara ${ }^{3}$ Y. Nakano ${ }^{3}$ H. Fujii ${ }^{1}$ J. Suzuki $^{2}$ I. Kakeya $^{3}$ K. Kadowaki ${ }^{3}$ K. Hirata ${ }^{1}$ H. Kito ${ }^{4}$ H. Ihara ${ }^{4}$

${ }^{1}$ National Institute For Materials Science Superconducting Materials Center 12-1, Sengen TSUKUBA IBARAKI 305-0047 JAPAN ${ }^{2}$ Japan Atomic Energy Research Institute ${ }^{3}$ Institute of Materials Scinece, University of Tsukuba ${ }^{4}$ National Institute of Advanced Industrial Science and Technology

Crystal structure of $\mathrm{Sr}_{2} \mathrm{YCu}_{2} \mathrm{FeO}_{6+\delta}$ and $\mathrm{Sr}_{2} \mathrm{YCu}_{2} \mathrm{CoO}_{6+\delta}$ has been analyzed using neutron powder diffraction. These compounds consist of nanometer-scale sequence of alternating double $\mathrm{CuO}_{2}$ sheets as those in high- $\mathrm{T}_{\mathrm{c}}$ superconductors, and $(\mathrm{Fe}, \mathrm{Co}) \mathrm{O}_{\delta}$ sheet similar to that in the $\mathrm{Sr}(\mathrm{Fe}, \mathrm{Co}) \mathrm{O}_{3-\delta}$ magnetic compound with brownmillerite-type structure. $\mathrm{Sr}_{2} \mathrm{YCu}_{2} \mathrm{FeO}_{6+\delta}$ exhibits superconductivity around $50 \mathrm{~K}$ when it is annealed under $\mathrm{N}_{2}$ atmosphere and subsequently under $\mathrm{O}_{2}$ atmosphere, while $\mathrm{Sr}_{2} \mathrm{YCu}_{2} \mathrm{CoO}_{6+\delta}$ with the same annealing process does not exhibit superconductivity. Neutron diffraction study indicates that it is easy to substitute $\mathrm{Cu}$ for $\mathrm{Fe}$ in $\mathrm{Sr}_{2} \mathrm{YCu}_{2} \mathrm{FeO}_{6+\delta}$ and the $\mathrm{N}_{2}$-annealing suppresses this substitution, while $\mathrm{Cu}$ is hardly substituted for $\mathrm{Co}$ in $\mathrm{Sr}_{2} \mathrm{YCu}_{2} \mathrm{CoO}_{6+\delta}$. The annealing process is very effective on the control of oxygen content, $6+\delta$, in $\mathrm{Sr}_{2} \mathrm{YCu}_{2} \mathrm{FeO}_{6+\delta}$, although the $\delta$ value do not deviate substantially from unity by the annealing process in $\mathrm{Sr}_{2} \mathrm{YCu}_{2} \mathrm{CoO}_{6+\delta}$. These results show that enough amount of oxygen cannot be supplied onto the $\mathrm{CoO}_{\delta}$ sheet to exhibit superconductivity in $\mathrm{Sr}_{2} \mathrm{YCu}_{2} \mathrm{CoO}_{6+\delta}$.

\section{Keywords: HIGH-TC SUPERCONDUCTOR, NEUTRON} DIFFRACTION, 1212 PHASE
Acta Cryst. (2002). A58 (Supplement), C157

X-RAY POWDER DIFFRACTION STUDY AND OPTICAL CHARACTERIZATION OF THE $\mathrm{Cu}\left(\mathrm{In}_{1-\mathrm{x}} \mathrm{Ga}_{\mathrm{x}}\right)_{3} \mathrm{Te}_{5}$ SEMICONDUCTING SYSTEM

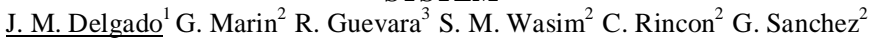
Universidad De Los Andes Facultad De Ciencias Depto. De Quimica Apdo. 40 La Hechicera MERIDA MERIDA 5251 VENEZUELA

${ }^{1}$ Laboratorio Nacional de Difraccion de Rayos-X, Facultad de Ciencias, Universidad de Los Andes, Apdo. 40, La Hechicera, Merida 5251, Venezuela. ${ }^{2}$ Centro de Estudios de Semiconductores, Facultad de Ciencias, Universidad de Los Andes, Apdo. 1, La Hechicera, Merida 5251, Venezuela. ${ }^{3}$ Laboratorio de Rayos-X, Seccion de Fisica, UNEXPO, Puerto Ordaz, Bolivar, Venezuela

Ingots of several compositions of the $\mathrm{Cu}\left(\mathrm{In}_{1-\mathrm{x}} \mathrm{Ga}_{\mathrm{x}}\right) \sim \mathrm{Te}_{5}$ semiconducting system were prepared by the Bridgman technique in a multi-zone vertical furnace. $\mathrm{X}$ ray powder diffraction and optical studies allowed to characterize the fundamental structural aspects and determine the energy band gap $\mathrm{E}_{\mathrm{g}}$. of these materials. The structural study carried out using powder diffraction data collected with a SIEMENS D-5005 diffractomer indicates that a solid solution is formed over the entire range of composition. The parameters a and $\mathrm{c}$ of the tetragonal chalcopyrite-related unit cell obtained vary from 6.1639(3) and 12.346(2) $\AA$ for $\mathrm{x}=0$ to 5.9321(8) $\AA$ and 11.825(4) $\AA$ for $\mathrm{x}=1$, respectively. The variation of the energy band gap with composition is linear, contrary to the quadratic relation of the form $\mathrm{E}_{\mathrm{g}}=\mathrm{a}+\mathrm{bx}+\mathrm{cx}^{2}$ observed in the $\mathrm{Cu}\left(\mathrm{In}_{1-\mathrm{x}} \mathrm{Ga}_{\mathrm{x}}\right)$ $\sim \mathrm{Se}_{5}$ semiconducting system.

This work was supported by grants from CONICIT and CDCHT-ULA.

\section{Keywords: SEMICONDUCTORS POWDER DIFFRACTION BAND} GAP
Acta Cryst. (2002). A58 (Supplement), C157

\section{RAPID HTXRD ANALYSIS OF PHASE EVOLUTION IN CERAMIC} MATERIALS

R. L. Snyder ${ }^{1}$ M. B. Dickerson ${ }^{1}$ K. Pathak ${ }^{1}$ J. Nash ${ }^{1}$ K. H. Sandhage ${ }^{1}$ U. Balachandran $^{2}$ B. Ma ${ }^{2}$ R. Blaugher ${ }^{3}$ R. Bhattacharya ${ }^{3}$

${ }^{1}$ Materials Science And Engineering The Ohio State University 2041 College Road COLUMBUS OH 43210 USA ${ }^{2}$ Argonne National Laboratory ${ }^{3}$ National Renewable Energy Laboratory

Inorganic chemical reactions responsible for the development of the microstructure and phases of technologically significant ceramic materials have been investigated with the use of rapid high-temperature $\mathrm{x}$-ray diffraction. To assist in the dynamic in situ study of materials processes involving volatile agents, X-ray transparent reaction vessels have been developed. These chemically inert and hermetically sealed cells serve to uniformly heat the sample and its enclosed environment while minimizing the loss of aggressive vapor species from the cells. Currently these cells are being employed in the previously impossible studies of applications such as the reduction of oxide ceramic precursors by reactive alloy liquids and phase evolution in thalliumbased cuprates. The investigation of such processes has been greatly enhanced by the use of a two-dimensional GADDS X-ray detector system, which enables the simultaneous analysis of texture and phase identification. Results of the 2D texture analysis of HTSC thin film materials prepared by Inclined Substrate Deposition and melt-texturing as well as phase evolution in several ceramic systems are presented.

Keywords: POWDER DIFFRACTION, HIGH TEMPERATURE DIFFRACTION, IN SITU DIFFRACTION 